\title{
Simulation Method - Based Oil Spill Pollution Risk Analysis for the Port of Šibenik
}

\author{
Goran Belamarića , Željko Kurtela ${ }^{b}$ Rino Bošnjak ${ }^{a}$
}

Statistical data, analyses and assessment of maritimepassenger traffic in sea ports in the Republic of Croatia pertaining to the traffic in the Port of Šibenik indicate that, following the expansion and reconstruction of berths for large ships in 2014, marine traffic in the waters of the Port of Šibenik and the Channel of St. Ante has been on the rise. There is therefore a need for pollution risk analysis for the Port of Šibenik. Risk assessment was made using the qualitative method of "Risk assessment-based threat ranking", following which a scenario involving discharge of harmful substances (oil spill) and possible pollution of the Port of Šibenik and the Channel of St. Ante in difficult navigating conditions in restricted waterways and bad weather was simulated. Marine pollution itself has no direct impact on human life. There are usually no human casualties, although major disasters can affect human health. There can therefore be dire indirect consequences, with negative impact on the eco-system, and consequently on some of the most important branches of industry like tourism, sports, fishing, etc.

The prevalent northerly and southerly winds have a particularly high influence on the spreading of oil spills in closedoff waters like those of the Port of Šibenik. The influence of sea currents in the Krka river basin and the Channel of St. Ante is exceptionally strong, especially during heavy rains accompanied by increased water flow. Oil spill simulation is therefore an important tool for planning preventive action and response operations in case of oil spill from ships.

\footnotetext{
a. University of Split, Faculty of Maritime Studies, Split, Croatia

e-mail: goran.belamaric@pfst.hr

b. Department of Maritime Studies, University of Dubrovnik, Dubrovnik, Croatia

e-mail: zeljko.kurtela@unidu.hr
}

\author{
KEY WORDS \\ $\sim$ Risk \\ $\sim$ Oil spill pollution \\ $\sim$ Simulation \\ $\sim$ Sea environment
}

\section{INTRODUCTION}

Since marine traffic of all types of vessels, especially recreational vessels and large cruisers, in the waters of the Channel of St. Ante and the Port of Šibenik significantly intensifies during summer, there is need for the analysis of risk of pollution and spreading of oil spills in case of an accident.

Accidents involving injury to passengers, crew and port employees, damage to the ship and operating coast, pollution of the marine environment and discontinuation of port operation seem to be a realistic possibility in this scenario.

Varlamov S.M., J.-H. Yoon, H. Nagaishi \& K. Abe "Japan Sea oil spill analysis and quick response system with adaptation of shallow water ocean circulation model" (Varlamov et al., 2000), and an especially large number of papers made by the National Oceanic and Atmospheric Administration (NOAA), titled "Oil Modeling Environment" (Barker, 2015; Varlamov et al., 1999) are of special relevance for pollution simulation.

This paper revolves around risk assessment and simulation of possible sea pollution by an oil spill from a ship, due to an accident occurring during the navigation of large commercial and passenger ships on approach to the Port of Šibenik, and especially in the Channel of St. Ante, while sailing towards/ departing from the Port of Šibenik.

The scenario of arrival of a large cargo ship into Port of Šibenik under difficult geographical and weather conditions 
was simulated using the $\mathrm{ADIOS}^{1}$ and $\mathrm{GNOME}^{2}$ models. A simulation of this type is presumed to be capable of providing important information for long-term and short-term (4-5 days as a minimum) planning of environmental protection operations and procedures in case of an oil spill.

The basic oil spill simulation applications are:

long-term planning of protection against oil spill pollution by analysis of the level of risk of environmental pollution from extant and future potential sources of oil spills for the most sensitive areas (supply, tourism, maritime farms and similar);

short-term planning of environmental protection and recovery. Anticipation of spill spread direction and manner of oil disposal for cleanup purposes.

The Channel of St. Ante is considered one of the 50 most demanding sea or river passages in the world. Since marine traffic peaks in the summer months, the risk of a maritime accident with grave consequences skyrockets in this period. There is therefore need for the assessment of the risk of possible pollution and anticipation of the consequences of an oil spill spreading in the Šibenik City Port and the Channel of St. Ante.

\section{RISK ASSESSMENT OF POSSIBLE OIL POLLUTION OF THE PORT OF ŠIBENIK}

Since a significant increase in marine traffic of all types of vessels, general cargo ships, ro-ro ships and especially cruisers and yachts is anticipated after the completion of reconstruction of berths in the Port of Šibenik, the risk of oil spill pollution due to collision, impact with the shore or grounding may realistically be expected to increase as well. These types of accidents can be caused by human error, dangerous navigation of large ships through the narrow Channel of St. Ante and/or bad weather conditions.

Owing to its natural characteristics and configuration, the Channel of St. Ante and Šibenik city and cargo port area are considered to be the most critical points of the fairway. The Channel of St. Ante is considered one of the 50 most demanding sea or river passages in the world. It is one nautical mile long, only

1. ADIOS (Automated Data Inquiry for Oil Spills) is a model of the sea surface oil spill spreading process, having at its disposal a database containing over one thousand refined raw oils and products, and giving an insight into the characteristics and assessments of the expected behavior of oil spilled into a marine environment. The predictions are presented both graphically and textually and designed to help answer questions usually accompanying oil spills and the resulting clean-up, e.g. can spilled oil still be dispersed by chemical dispersants or help anticipate the rate of increase of the water content in oil over a period of time.

2. GNOME (General NOAA Oil Modeling Environment) is a publically available simulation model of pollution movement due to the spillage of oil, and a simulation of the trajectory of oil spill spreading and dispersion under the influence of the wind, sea currents and tides. The program was developed by the Hazardous Materials Response Division (HAZMAT) of the National Oceanic and Atmospheric Administration Office of Response and Restoration (NOAA OR\&R).
130 meters wide in the narrowest part, and 23-30 meters deep. Since the sea along its rocky and exceptionally steep coastline is interspersed with shallows, ship trajectories have to be frequently modified. Tow-boat assistance is therefore recommended for large cargo and/or passenger ships ( $200 \mathrm{~m}$ long, $23 \mathrm{~m}$ wide, with a $10 \mathrm{~m}$ draught). Very limited maneuvering and turning space is sufficient evidence of the demanding nature of the fairway, and increases the risk of occurrence of all types of maritime accidents.

Navigation through the channel is additionally aggravated by the fact that a large ship on the move is extremely difficult to stop. Every attempt to navigate in the direction of the port is also aggravated by the sea currents flowing in the counter direction. Any ship with a deep draught has large undersea surface, contributing to significant starboard pull when exposed to a strong sea current, aided by ship inertia during turns, requiring the control of ship movements by speed modifications.

Due to the geographical position and natural enclosure of the Port of Šibenik, the spillage of 700-800 tons of oil into the sea would have immeasurable consequences - the Port of Šibenik and the Channel of St. Ante would be subject to long-term pollution.

Since oil spreads across sea surface after spillage, sea currents significantly influence its spreading patterns. The most frequently occurring winds should also be considered, since they would have the greatest effect on the spread of pollution.

Risk assessment needs to be made in advance to ensure faster and more efficient action in case of maritime accidents and pollution of the waters of the Port of Šibenik and facilitate the determination of the required level of protection. The assessment of the risk of occurrence of a maritime accident depending on vessel type, size and speed, cargo type and value, danger of the cargo to the sea and the environment, etc. should be made before a vessel enters a heightened-risk area like the Port of Šibenik.

Applying the criteria defined in "PIANC - Approach Channels Design Guidelines", the analysis of the risk of possible pollution by spillage of oil from a ship over a time period is based on the following (Statistički meteorološki podatci za područje akvatorija luke Šibenik, 2015; Admirality Sailing Direction NP 47, 2005; Approach Channels Design Guidelines, 2014):

1. characteristics of the Channel of St. Ante and the Port of Šibenik and the dangers posed by the very configuration of the local waters and coastline:

Fairway configuration: approach to port (fairway depth and width) - passage through the Channel of St. Ante, turning point, locations of wrecks and shallows and other dangers;

Navigation aids: buoys (types and characteristics), covered routes, lighthouses;

Conditions in the port: navigation practices, tow-boat availability, different limitations pertaining to making port, docking and departure from port, type and sizes of vessels visiting the port. 
2. Weather conditions:

local wind direction and speed,

visibility.

Strong NE (Bura) and SE (Scirocco) winds blowing in winter merit special attention. They blow counter to the general sea current direction. Currents in the Channel of St. Ante continuously flow westward and reach maximum strength along the northern part of the channel, achieving the speeds of up to 3 knots during winter and $1 / 2$ knot during summer, with Bura adding to the speed of the sea current. During summer, it rarely blows for more than a couple of consecutive hours and usually stops within one or two days.

Jugo - southerly wind, most frequently blows for several days and is a harbinger of clouds and rain.

Maestral - north-westerly wind, blowing on sunny days. Usually starts to blow around 11 a.m. and stops in the late afternoon.

Nevera - strong westerly in the form of a storm. Although sudden and intense, summer storms are short-lived.

3. Sea currents, current direction and speed:

- $\quad$ Since the Port of Šibenik is situated in the mouth of the Krka river, the effect of sea currents is continuously very intense, especially during heavy rains accompanied by increased water flow.

During navigation through the Channel of St. Ante, special attention needs to be paid to the eastern $(E)$ entrance into the channel, particularly when sailing in the vicinity of the Cape of Burnji Turan $\left(43^{\circ} 43,7^{\prime} \mathrm{N} 15^{\circ} 53,1^{\prime} \mathrm{E}\right)$ due to the strong SE current.

Risk assessment was made based on the recognized and identified possible risks. Risk identification allows it to be analyzed and plans for its reduction, monitoring and supervision made, meeting the preconditions for risk management (Bukša and Zec, 2005). Potential threats may either take advantage of a system vulnerability or be independent of the system's safety. Potential sources of threats are resource errors or failures (errors made by automated steering systems, failure of a particular ship device, etc.), accidents (fire, main engine failure, weather conditions, grounding, collision, sea and/or air pollution, etc.), human error and similar.

Risk management is the process of verification of business justification of selected safety solutions and controls intended to provide a sufficient level of safety. Risk management consists of three processes: risk assessment, risk reduction and residual risk assessment (Alagić et al., 2011).

To reduce the danger of pollution of the sea and the marine environment, Port Authority should, in the framework of measures of safe navigation in the waters of a high-risk port, conduct a risk assessment in advance and select the measures of the possible level of protection. Port Authority should therefore conduct an advance risk analysis for a particular vessel, depending on its type, size, speed, type and value of cargo, danger of the cargo to the ship and the environment, etc.

The "Risk assessment-based threat ranking" qualitative method (based on descriptions or ranking) was used for risk assessment calculation. This risk assessment method formally makes use of only two parameters: impact on the asset (asset value) and probability of risk realization. Impact on the asset is implicitly assumed to be equivalent to asset value, while threats are examined with respect to corresponding vulnerabilities. The assessed risk thus becomes a multi-parameter function (Hutinski and Krakar, 2002; BERR, 2008):

$R=f\left(P_{V, T^{\prime}} I_{A V, T}\right)$

P probability of risk realization;

I possible consequences (Impact) of threat realization;

$\mathrm{V}$ resource vulnerability, i.e. potential for its exploitation with possible unwanted consequences of present or planned preventive measures capable of reducing the risk of vulnerability, threats and consequences;

$\mathrm{T}$ threats capable of taking advantage of vulnerabilities;

AV asset value, i.e. the likelihood of its realization having a potentially harmful effect on the asset;

$A$ variation of this method uses the same value range for impact (AV) and the probability of risk realization (P). Possible values range from 1 (small) to 5 (very high). The level of risk is determined by the product of these two parameters.

Minimum and maximum values of risk assessed using formulas 2 and 3 can be obtained using formula 1 and the value range indicated in (Alagić et al., 2011).

Minimum and maximum values of an assessed risk are as follows:

$R_{\text {MIN }}=P_{\text {MIN }} \cdot I_{M I N}=1$

$R_{\text {MAX }}=P_{\text {MAX }} \cdot I_{\text {MAX }}=25$

An assessed risk may be expressed in whole-number values between and including RMIN and RMAX, but excluding simple numbers outside that value range and their multiples (Alagić et al., 2011; Hutinski and Krakar, 2002). Risk assessment-based threat ranking allows the prioritization of threats in the later stages of risk management.

Threat identification is followed by an assessment of the probability of threat realization $P(T)$ ) and its consequences (or Threat impact - I(T)) (Alagić et al., 2011). Threat realization probability and its consequences are assessed using the same value range utilized to determine asset value: insignificant (1), low (2), medium (3), high (4), very high (5). Finally, risk is assessed. The level of risk is determined using the established risk assessment methodology, as the product of those two factors: $R=P *$. 
The assessment of the level of risk of pollution from oil spill from a ship is therefore based on the risk assessment-based threat ranking matrix. The Data Risk Assessment List matrix was used (5x5). The matrix includes a standard qualitative matrix with the corresponding threat level colors (green, yellow, red) and value designations 1-25 (Table 1).

Table 1.

Risk assessment-based threat ranking matrix $(5 \times 5)$.

\begin{tabular}{|c|c|c|c|c|c|c|c|}
\hline & & & \multicolumn{5}{|c|}{ Consequences } \\
\hline & & & insignificant & small & medium & grave & very grave \\
\hline & & & (1) & (2) & (3) & (4) & (5) \\
\hline \multirow{5}{*}{ 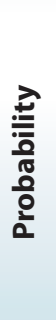 } & 1 & $\begin{array}{l}\text { Possible, but only under rare and } \\
\text { extraordinary conditions }\end{array}$ & 1 & 2 & 3 & 4 & 5 \\
\hline & 2 & Could happen, but probably never will & 2 & 4 & 6 & 8 & 10 \\
\hline & 3 & $\begin{array}{l}\text { Could and probably will happen at some } \\
\text { time }\end{array}$ & 3 & 6 & 9 & 12 & 15 \\
\hline & 4 & Can probably frequently happen & 4 & 8 & 12 & 16 & 20 \\
\hline & 5 & Almost certain to happen in most cases & 5 & 10 & 15 & 20 & 25 \\
\hline
\end{tabular}

The development of the risk assessment-based threat ranking matrix (Table 1) is followed by the establishment of risk indicators (Table 2). The level of risk acceptability is determined for each analyzed event separately. Risk level indicator is determined by an interested user after the evaluation of all risk calculation factors used. The following risk indicators are used to estimate the level of risk

Table 2.

Risk indicators.

Risk indicators

$\begin{array}{ll}1-6 & <40 \% \\ 7-14 & >45 \%,<65 \% \\ 15-25 & >65 \%\end{array}$

\section{Level of acceptability}

insignificant or small consequences acceptable risk medium consequences

grave or very grave consequences unacceptable risk
The results of assessment of individual and total risk levels in case of pollution of the marine environment by oil spillage from a ship into the sea:

The first step in risk level determination is the quantification of consequences in case of pollution, followed by the calculation of the overall assessment of risk of pollution based on the Consequence (threat) quantification table and the values ranked therein:

- $\quad \mathrm{T} 1$ - Pollution consequence quantification with respect to the configuration of the Port of Šibenik

- $\quad$ T2 - Pollution consequence quantification with respect to the configuration of the Channel of St. Ante

- $\quad$ T3 - Pollution consequence quantification with respect to sea currents and weather conditions

- $\quad$ T4 - Pollution consequence quantification with respect to ship type (High Risk Ships)
- $\quad$ T5 - Pollution consequence quantification with respect to time of year and density of traffic

- $\quad$ T6 - Pollution consequence quantification with respect to preventive measures at local community level

- $\quad$ T7 - Pollution consequence quantification with respect to navigation aids and port customs

- T8 - Pollution consequence quantification with respect to the characteristics of the transported cargo

- $\quad$ T9 - Pollution consequence quantification with respect to navigation with tow-boat assistance

- TTL10 - Calculation of individual and total level of risk of pollution.

Each above table from T1-T9 consists of a certain number of questions. Each question has several values assigned (reference data from specially designated tables). Every value $(P)$ has several offered answers. Every answer is scored from 1-5 depending on 
Table 3.

T3 - Quantification of consequences for the ship with respect to sea currents and weather conditions.

\begin{tabular}{llll}
\hline $\mathbf{2}$ & Weather conditions & Value & Consequences \\
\hline 2.1 & Time of day and visibility & Day & 15 \\
\hline 2.2 & Visibility in fog or haze & Small $<4 \mathrm{Nm}$ & 15 \\
\hline 2.3 & Wind direction and strength & Northeasterly $>$ Bf 2 & 25 \\
\hline 2.4 & Condition of the sea & $0,5-1,5 \mathrm{~m}$ & 16 \\
\hline 2.5 & Sea currents & lateral $<2$ knots & 20 \\
\hline Weather conditions & & 91
\end{tabular}

Table 4.

Reference data for T3.

BT2

Question

2.1

2.3

2.4

2.2

2.4

2.5

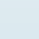$$
<\mathrm{NIL}>
$$

bow 1-3 knots

lateral $<2$ knots

lateral 3 knots and $>3$

T2

\section{Weather conditions}

Value $(P)$

$<\mathrm{NIL}>$

Day

Twilight

$\langle\mathrm{NIL}>$

High $>7 \mathrm{Nm}$

Acceptable 4-7 Nm

$>1,5$

Points

Impact

Max POINTS

0

5

5

$\begin{array}{ll}3 & 5 \\ 4 & 5\end{array}$

5

5

25

5

5

5

Small $<4 \mathrm{Nm} \quad 5$

$<\mathrm{NIL}>\quad 0 \quad 5$

$\mathrm{Bf}=0 \quad 0 \quad 5$

Southeasterly $<$ Bf $2 \quad 2$

Southeasterly $>$ Bf $2 \quad 3 \quad 5$

Northeasterly $<$ Bf $2 \quad 4 \quad 5$

Northeasterly $>$ Bf $2 \quad 5 \quad 5$

$<\mathrm{NIL}>\quad 0 \quad 4$

$0-0,5 \mathrm{~m} \quad 3$

$0,5-1,5 \mathrm{~m} \quad 4 \quad 4$

5

0

$1 \quad 5$

$4 \quad 5$

$5 \quad 5$

5

25

4

4

4

5

5

525

120 
the selected answer. Every set of questions has its weight, i.e. impact, also scored 1-5. The product of multiplication of scores and impacts indicates the magnitude of consequences for the selected answer, ranging from minimum 1 to maximum 25 . Every table thus has its maximum number of points and a total number of points per set of questions, depending on selected questions. The final value of the risk for the observed table (set) and the total level of risk are obtained from the above figures.

Reference values of classified factors used in tables T1-T9 are based on the requirements of PIANC (Approach Channels Design Guidelines, 2014) recommendations of the ADMIRALTY SAILING DIRECTION NP 47, Mediterranean Pilot Vol.3, pertaining to the local waters of the Port of Šibenik and statistical meteorological data of the Croatian Meteorological and Hydrological Service (Statistički meteorološki podatci za područje akvatorija luke Šibenik, 2015).

An example of risk analysis factor processing with respect to sea currents and weather conditions:

In Table 3 (T3), the consideration of possible weather conditions is made for unfavorable conditions for ships in transit.

The methodology for the calculation of individual and overall risk levels using Tables T1-T9 and their reference values indicated in the Table of reference data, may yield an unlimited number of combinations. A detailed risk assessment methodology requires the Table of quantification of consequences of pollution and reference data for each table.

Table 5 .

Calculation of individual and overall pollution risk levels.

\section{Calculation of individual and overall pollution risk levels}

\begin{tabular}{|c|c|c|c|c|c|c|c|c|c|c|}
\hline Set & $\begin{array}{l}\text { T1. } \\
\text { Configura- } \\
\text { tion of the } \\
\text { Port of } \\
\text { Šibenik }\end{array}$ & $\begin{array}{l}\text { T2. } \\
\text { Configura- } \\
\text { tion of the } \\
\text { Channel } \\
\text { of St. Ante }\end{array}$ & $\begin{array}{l}\text { T3. } \\
\text { Sea cur- } \\
\text { rents and } \\
\text { weather } \\
\text { conditions }\end{array}$ & $\begin{array}{l}\text { T4. } \\
\text { Ship type }\end{array}$ & $\begin{array}{l}\text { T5. } \\
\text { Time of } \\
\text { year and } \\
\text { traffic } \\
\text { density }\end{array}$ & $\begin{array}{l}\text { T6. } \\
\text { Preventive } \\
\text { measures } \\
\text { at local } \\
\text { commu- } \\
\text { nity level }\end{array}$ & $\begin{array}{l}\text { T7. } \\
\text { Naviga- } \\
\text { tion aids }\end{array}$ & $\begin{array}{l}\text { T8. } \\
\text { Cargo } \\
\text { character- } \\
\text { istics }\end{array}$ & $\begin{array}{l}\text { T9. } \\
\text { Tow-boat } \\
\text { assisted } \\
\text { naviga- } \\
\text { tion }\end{array}$ & $\begin{array}{l}\text { TTL10. } \\
\text { TOTAL }\end{array}$ \\
\hline Set total \# & 143 & 108 & 91 & 88 & 90 & 70 & 82 & 31 & 64 & 767 \\
\hline Maximum & 212 & 172 & 120 & 115 & 100 & 125 & 115 & 81 & 84 & 1124 \\
\hline $\begin{array}{l}\text { Maximum } \\
\text { for the set } \\
\text { (\%) }\end{array}$ & 56 & 63 & 76 & 77 & 90 & 56 & 71 & 38 & 76 & 68 \\
\hline $\begin{array}{l}\text { Risk } \\
\text { indicator }\end{array}$ & Red & Yellow & Red & Red & Red & Yellow & Red & Green & Red & Red \\
\hline
\end{tabular}

\begin{tabular}{ll}
\hline & Level of risk \\
\hline$>65 \%$ & Red \\
\hline$>45 \%,<65 \%$ & Yellow \\
\hline$<40 \%$ & Green \\
\hline
\end{tabular}

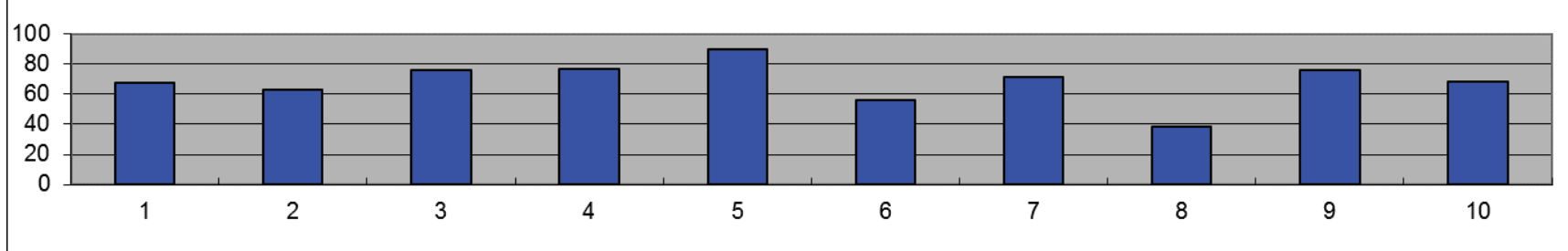

Since the risk analysis and assessment pointed to very high potential danger from pollution in case of a marine accident, a simulation of the pollution scenario was conducted to account for all possible consequences. 


\section{PORT OF ŠIBENIK POLLUTION SCENARIO}

The goal of the simulation conducted using computer programs for pollution spread anticipation is the establishment of possible pollution levels. Specific geographical configuration and unfavorable weather conditions make ship maneuvering more demanding and difficult, increasing the risk of accident occurrence and the consequent rapid oil spill spread under the influence of (strong) winds and the incessant sea current.

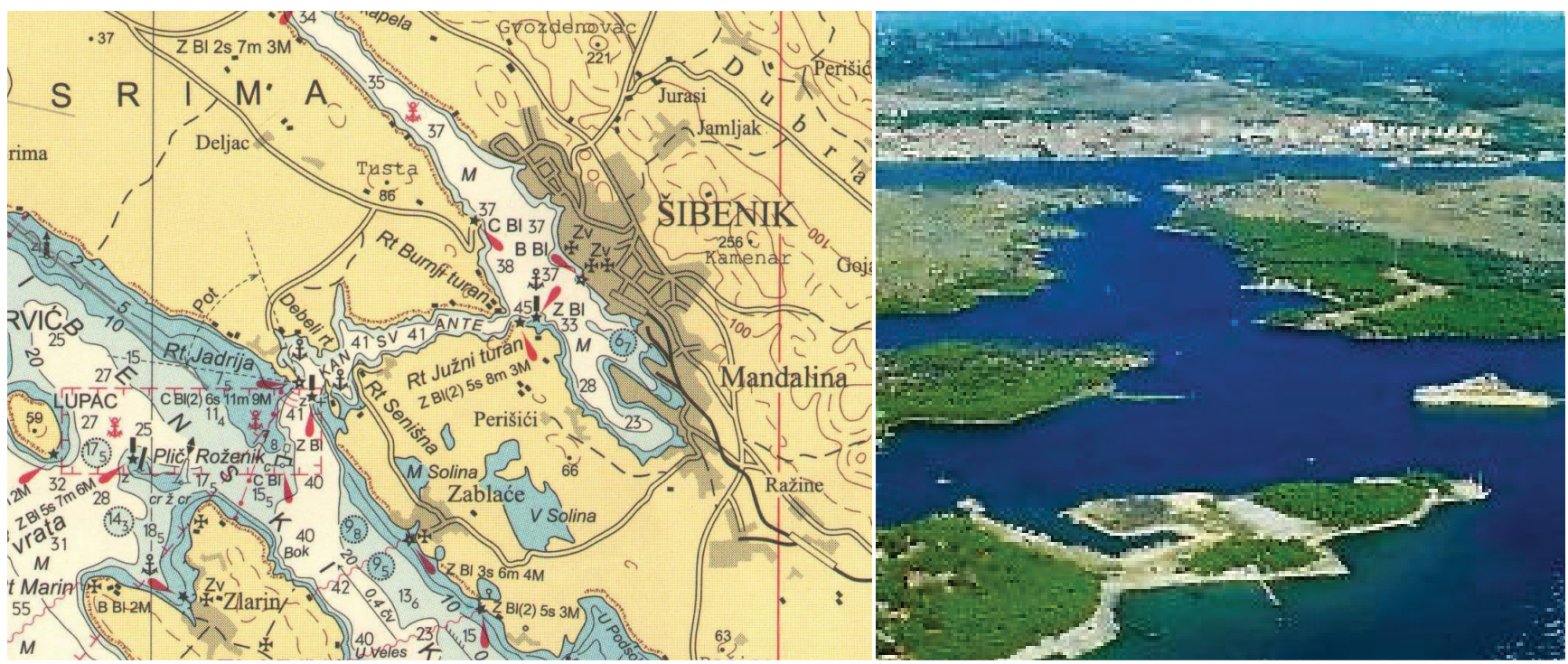

Figure 1.

Local waters of the fairway of the Port of Šibenik, Channel of St. Ante and Port of Šibenik.

This scenario was chosen due to it being one of the most critical stages of arrival into/departure from the Port of Šibenik. Passing through this location always comes with the potential risk of the vessel coming into physical contact with the shore/ bottom.

A commercial ship having the dimensions of $200 \times 23$ meters and a 10 meter draught navigates through the Channel of St. Ante at the speed of 6-8 knots with the intention of sailing into the Port of Šibenik. To avoid strong starboard pull, on the eastern side of channel exit-entrance into the waters of the Port of Šibenik, in the vicinity of the Cape of Burnji Turan, under the strong influence of the NE wind and the SE current suddenly picking up strength at the Cape of Burnji Turan, the ship comes into close proximity of the northern side of the shore.

After passing the Cape of Burnji Turan, the bank effect occurs, increasing the ship's squat. The ship makes contact with the bottom, its hull is damaged in the heavy fuel tank area (L20 $x \mathrm{~B} 6 \times \mathrm{H} 4)$ loaded to $70 \%$ of its capacity. The damage resulting from the impact of the ship into rocky bottom is square in shape, having the dimensions of $3 \times 3$ meters, at the height of 2 meter from tank bottom. Other relevant data used in the simulation (as constituent elements of the simulation program's database), pertaining to pollutant type (type of oil), water characteristics, dominant sea current, wind direction in the waters of the Port of Šibenik during the spread of pollution from the moment of spillage to the beginning of cleanup operations are as follows:

As illustrated in Figure 1 made in the Automated Data Inquiry for Oil Spills - ADIOS2 program, approx. $696 \mathrm{~m}^{3}$ of heavy fuel would be released into the sea from the damaged fuel tank in the course of 109 seconds (Figure 4).

When all the above data are transferred into the GNOME pollution spread simulation program, we can track the movement of the oil spill under the influence of the wind, sea and currents in real time and in the selected waters (eastern entrance into the Channel of St. Ante, in the vicinity of the Cape of Burnji Turan $\left(43^{\circ} 43,7^{\prime} \mathrm{N} 15^{\circ} 53,1^{\prime} \mathrm{E}\right)$ ) (Figures 5 and 6$)$. 
Table 6

Simulation input data.

\section{OIL TYPE}

DORROOD, OIL \& GAS (IRANIAN)

$\mathrm{API}=33.6$

Density

Viscosity
Synonyms = none listed Product Type $=$ crude Pour Point $=-20 \mathrm{deg} C$ Flash Point $=$ unknown $0.867 \mathrm{~g} / \mathrm{cc}$ at $11 \mathrm{deg} \mathrm{C}$

25.7 cSt at $11 \mathrm{deg} C$

\section{Sea Water Properties}

Temperature

Salinity

Sediment load at mouth of the river

$110 \mathrm{C}$

$15 \mathrm{ppt}$

$50 \mathrm{~g} / \mathrm{m}^{3}$ (avg. river/estuary)

\section{Sea Currents}

2.3 knots towards 160 degrees

\section{Wind and Wave Conditions}

Wind

Winds Start $=$ Feb. 05, 01:00 hours

Winds Stop $=$ Feb. 09, 01:00 hours

\section{Release Information - Leaking Tank Release}

Time of pollution release

February 05, 0100 hours

\section{Data on mechanical cleanup operations}

Time of application

February 06, 0800 hours

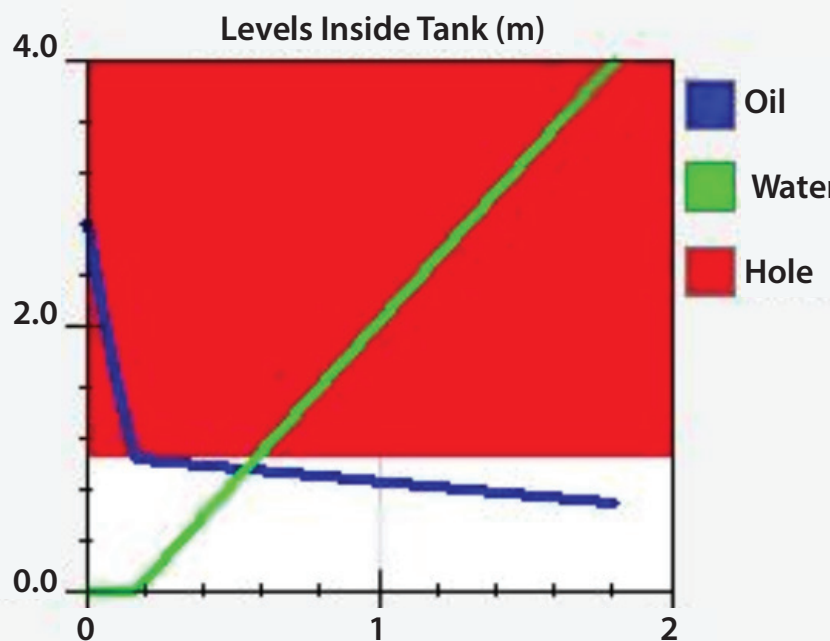

Time in Minutes

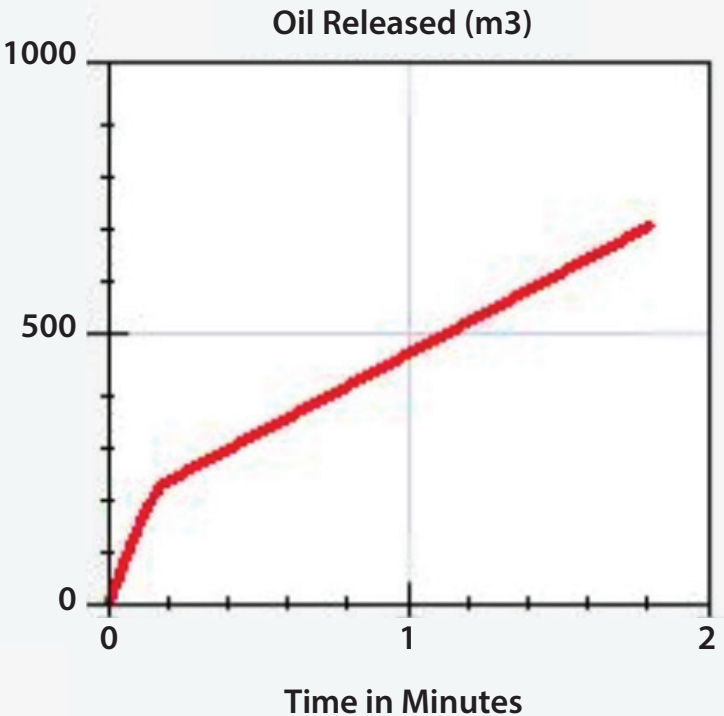

Figure 2

Illustration of release of oil from a tank with square-shaped damage, having the dimensions of $3 \times 3 \mathrm{~m}$. 


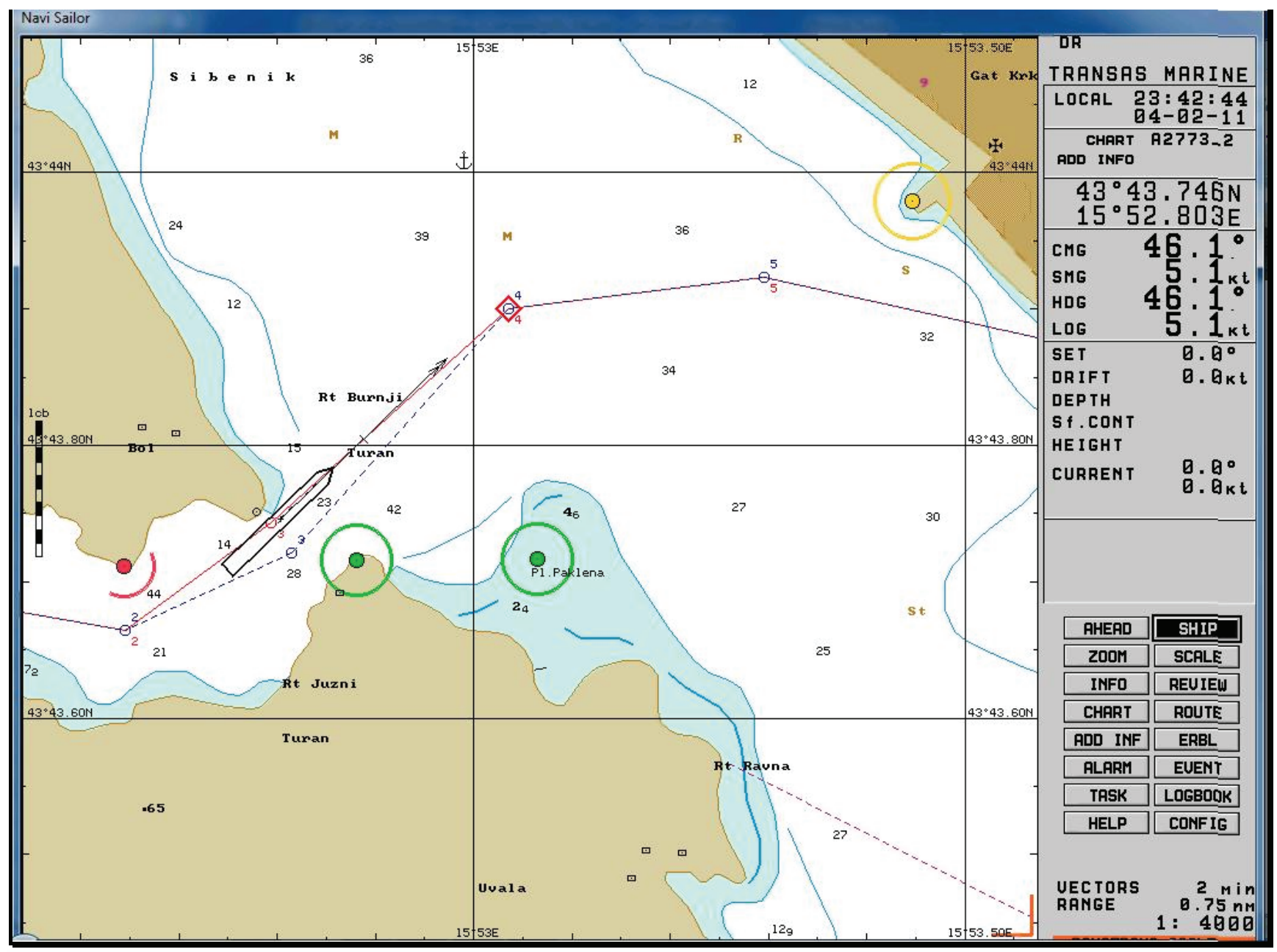

Figure 3.

TRANSAS ECDIS Tsunami99 - ship course.
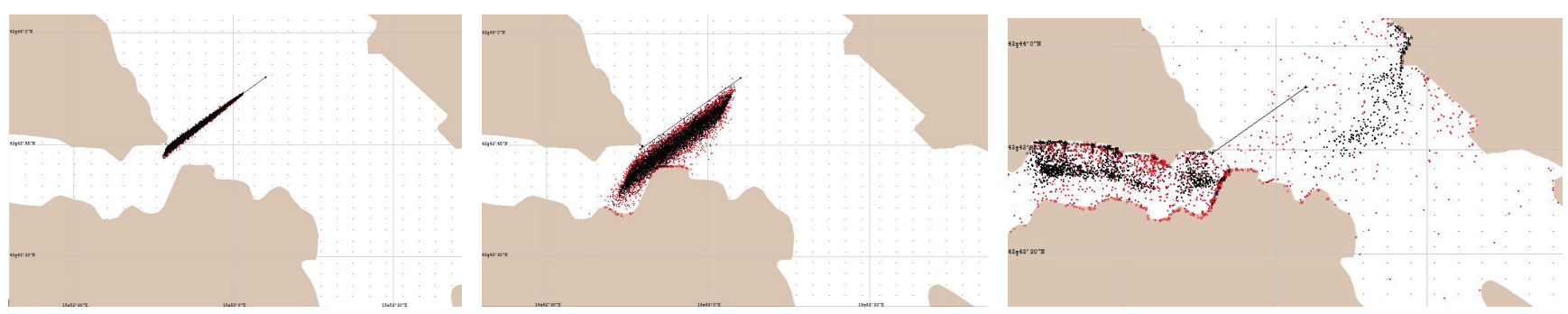

Figure 4.

GNOME oil spill spread simulation (step 1. 0-30 min, step 2. $30 \mathrm{~min}-90 \mathrm{~min}$, step 3. $90 \mathrm{~min}-96 \mathrm{hrs}$ ). 
The simulation illustrates the area of oil spill spread, depicted by black and red spots, over a 96 hour period (4 days). The understanding of the GNOME simulation requires two things to be taken into consideration:

1. Black spots represent the GNOME's best guess at the projected oil spill trajectory, under the assumption that wind speed and direction remain unchanged and that the data in the filled-in database indicate the exact and accurate position, direction and strength of the current at the time of oil release (Risk Assesment Template, 2015; GMONE, 2015).

2. Red spots represent the GNOME's estimated minimum error with respect to oil spill spreading, considering the level of uncertainty of the entered wind and current data. Data used in the modelling of the oil spill scenario indicate that $90 \%$ of the oil spill will remain inside the area covered by red spots (Risk Assesment Template, 2015; GMONE, 2015).

In this case, pollution spread illustrated in the simulation Figures is influenced by the predominant northeasterly wind, with the tendency of its subsequent transition into the southeasterly.
Owing to the location of the initial pollution, the northeasterly presents the greatest danger for the Channel of St. Ante, while the southeasterly scatters the pollution across a wider area, even inside the waters of the Port of Šibenik. Conducting the greatest possible number of spillage simulations is of utmost importance for any further analysis of projection of possible spreading of pollution across an enclosed water area. Every simulation must take into consideration the impact of sea currents and winds of varying strength and direction.

In addition, the simulation of the Automated Data Inquiry for Oil Spills - ADIOS2 illustrates oil spillage from the tank into the sea based on the parameters of the previously described case. Diagrams obtained by running the simulation provide data on oil distribution status, quantity of cleaned up oil (\%), water content in oil (\%), viscosity, quantity of evaporated oil (\%), oil density $(\mathrm{kg} /)$, content of evaporated fuel in the air (ppm), beached oil (\%), remaining oil (\%), (cleaned up, evaporated, beached, remaining).

Figure 7 , covering a 96 -hour period, illustrates the status (\%) of the remaining, cleaned up, evaporated and beached oil.

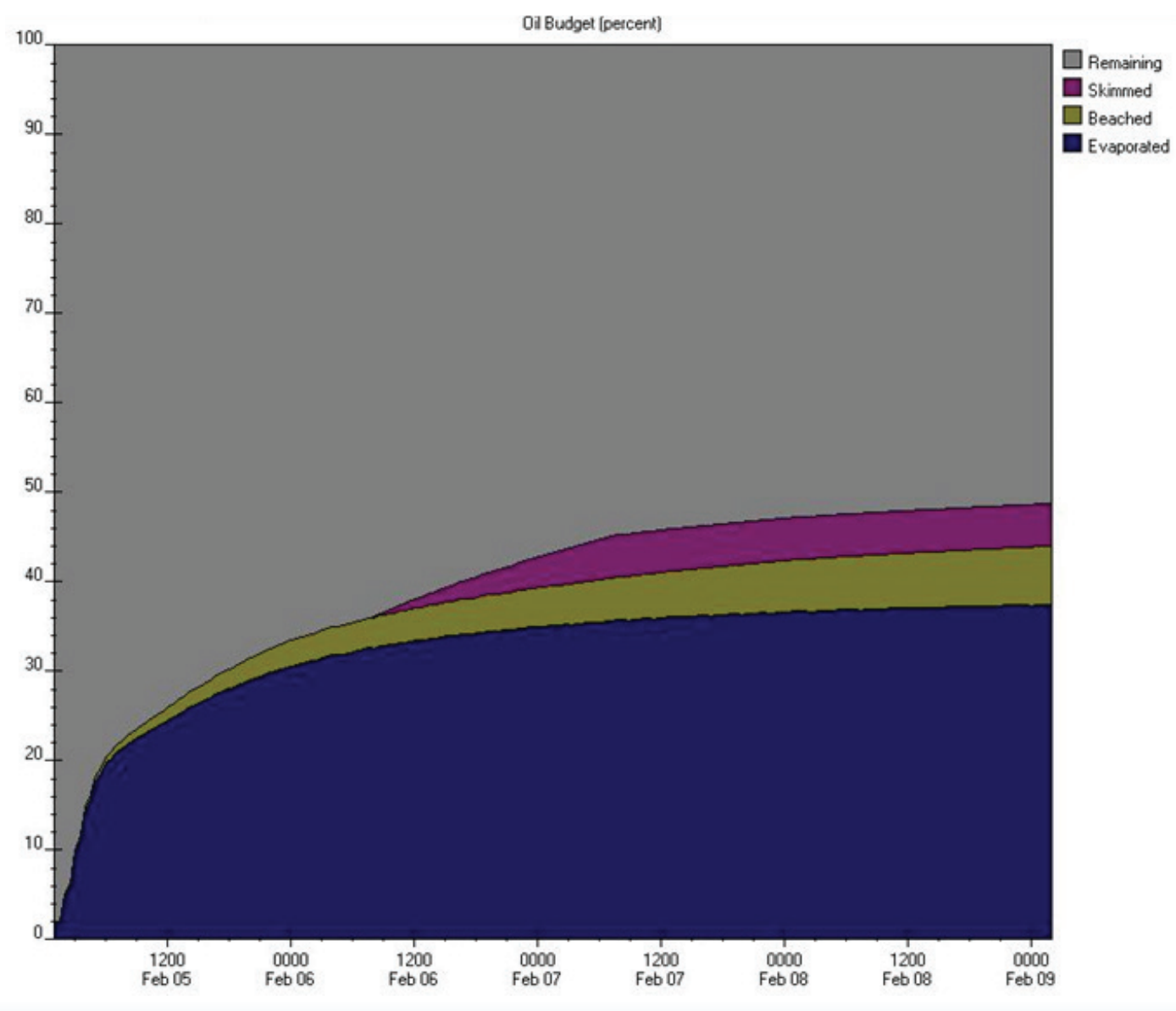

Figure 5.

Simulated oil distribution status diagram (\%) (remaining, cleaned up, beached and evaporated) over a 96-hour period. 
The diagrams clearly indicate that the quantity of evaporated oil reaches it maximum of approximately $35 \%$ (Figure 7) within the first 36 hours, with the quantity of evaporated gasoline vapors peaking in the first 3-6 hours (up to 45 ppm) after spillage, followed by a sudden drop, and amounting to a mere 0,01 ppm (Figure 8) 12 hours after spillage.

Oil spill spreading dilutes the spill (Figure 9).

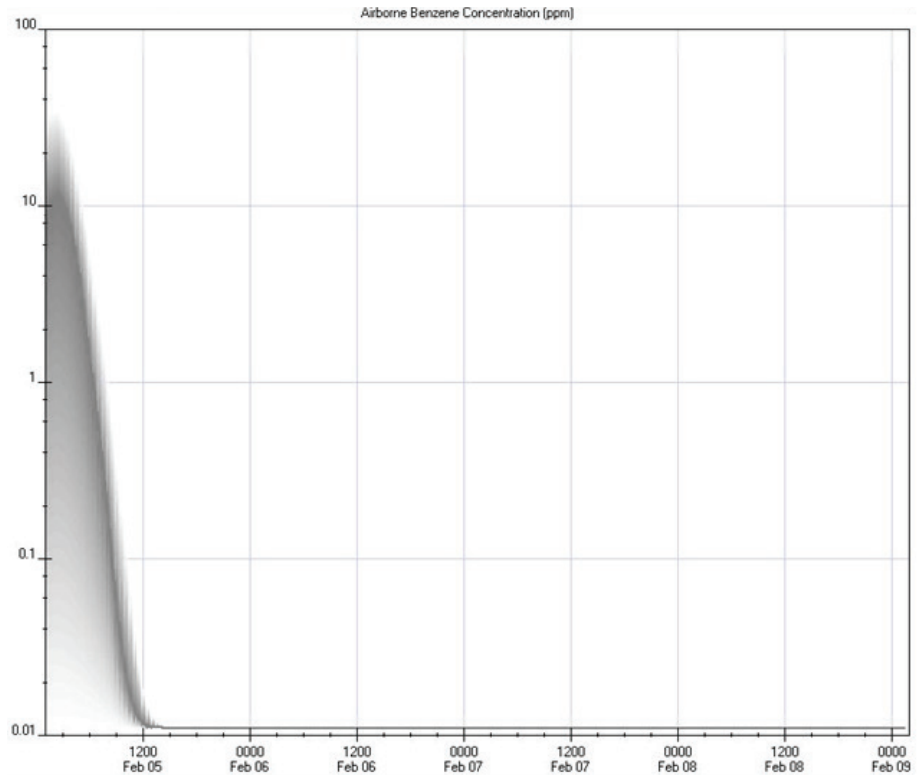

Figure 6.

Diagram of simulated status of evaporated gasoline in the air (ppm) over a 96-hour period.

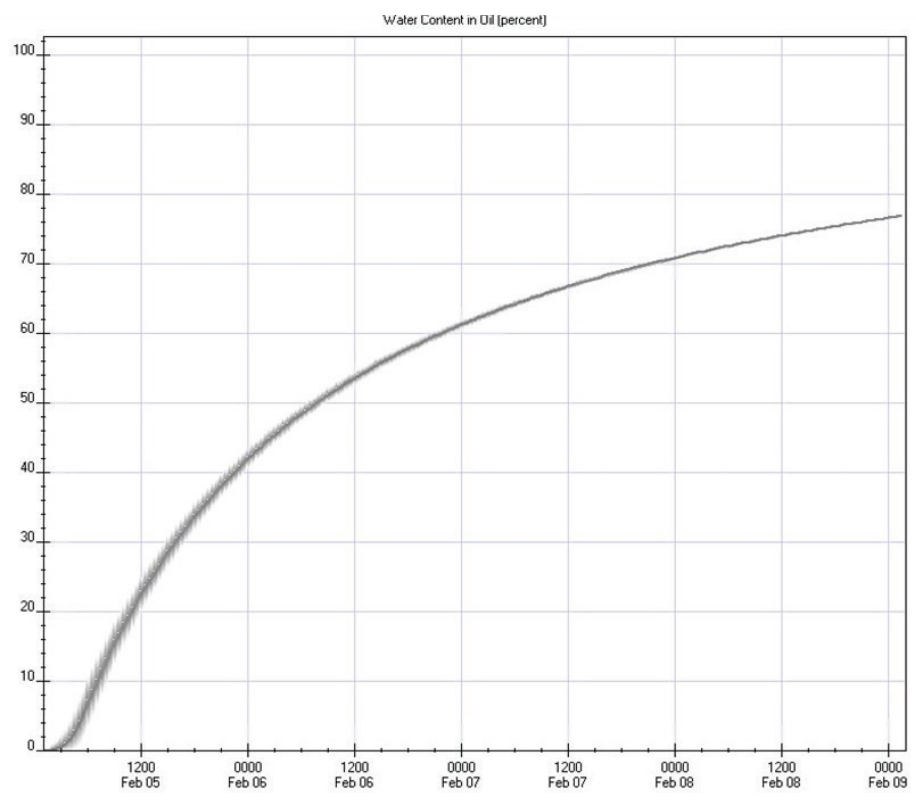

Figure 7.

Diagram of simulated status of water content in oil (\%) over a 96-hour period. 
Almost $55 \%$ of the oil remained uncollected after approximately 36 hours of evaporation, beaching (day $1=20 \mathrm{~m}^{3}$, day $2=10 \mathrm{~m}^{3}$, day $3=10 \mathrm{~m}^{3}$, day $4=5 \mathrm{~m}^{3}$, day $\left.5=5 \mathrm{~m}^{3}\right)$, skimming and clean-up operations (Figure 7).

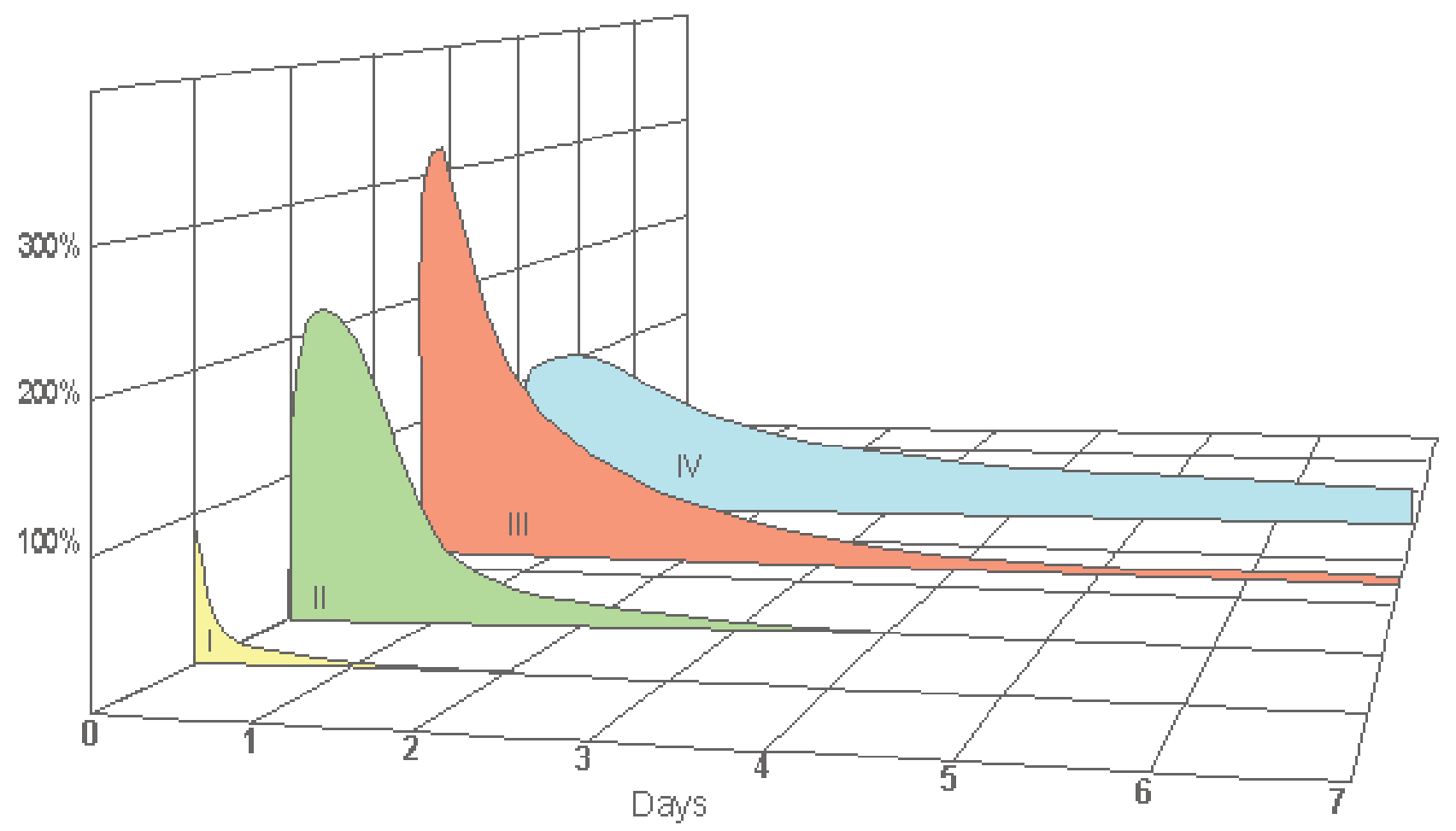

Figure 8.

Percentage of oil skimmed from sea surface by oil type (Varlamov and Abe, 2000).

$\begin{array}{ll}\text { Group } & \text { Density } \\ \text { Group I } & \text { less than } 0.8 \\ \text { Group II } & 0.8-0.85 \\ \text { Group III } & 0.85-0.95 \\ \text { Group IV } & \text { greater than } 0.95\end{array}$

The simulation illustrates that instantaneous reaction and reduction of the oil spill to the minimum are of utmost importance in case of unexpected pollution.

Pollution with large oil quantities would require, if possible, scouting from a plane, helicopter and/or by drone (or ship if the former are not available). Long-term weather forecast should then be consulted and the pollutant clean-up process initiated by removing the source of the spill, limiting oil or oil mixture spread, collecting oil or oil mixture, cleaning the coastline and disposing of the collected material.

\author{
Examples \\ Gasoline, Kerosene \\ Gas Oil, Abu Dhabi Crude \\ Arabian Light Crude, North Sea Crude Oils \\ Heavy Fuel Oil, Venezuelan Crude Oils
}

\section{CONCLUSION}

Since a significant increase in marine traffic of all types of vessels - general cargo ships, ro-ro ships and especially cruisers and yachts - is anticipated after the completion of reconstruction and expansion of the passenger terminal in the Port of Šibenik, the risk of oil spill pollution due to collision, impact with the shore or grounding, caused by human error or technical failure, may realistically be expected to increase as well.

The improvement of measures of rapid and efficient action in case of a marine accident and the consequent pollution 
of the waters of the Port of Šibenik requires not only prior risk assessment, but likewise the selection of the possible level of protection and determination of actions to be taken in emergency situations on the basis of such assessment. Such detailed analysis and assessment for the waters of the Port of Šibenik have yet to be made. Risk assessment of a marine accident taking into consideration vessel type, size and speed, cargo type and value, danger of the cargo for the ship and the environment, etc. should thus be made prior to a ship's arrival into a heightened-risk area, like the Port of Šibenik due to its geographical position and surroundings.

Since the analysis of the possible consequences of oil spill pollution has likewise never been made for the waters of the Port of Šibenik, the numerical simulation of an oil spoil, especially considering the natural surroundings of the port situated at the mouth of the Krka river, provides valuable information with respect to short-term and long-term (minimum 5 days) planning of environmental protection operations and procedures in case of an oil spill. Simulation results are dependent upon a large number of factors and characteristics of the initial oil spill (e.g. pollution location and intensity, oil spreading pattern). These factors are often either unknown or only partially known. Relevant data can be obtained by the parallel calculation of several different pollution scenarios and the analysis of likelihood of oil spill outcomes, and used to improve the prediction system. Meteorological and sea current simulation subsystems are of great importance for successful response to an oil spill and prediction of pollution spreading patterns. They can significantly improve the prediction of possible pollution, its spreading patterns, monitoring and clean-up.

The part of the subsystem used for oil spill simulation in the further analysis of pollution spreading pattern prediction is also relevant for an efficient response to an oil spill and the prediction of pollution spreading patterns by means of an oil spill simulation.

\section{REFERENCES}

Admirality Sailing Direction NP 47, (2005), Mediterranean Pilot Vol. 3, UK Hydrofraphic Office.

Alagić, D., Vagner, M. and Branković, V., (2011), Pojednostavljenje primjene metode procjene rizika uz regionalizaciju prijetnji informacijskom sustavu, Vara din: University of Zagreb, Faculty of Organization and Informatics.

Approach Channels Design Guidelines, (2014), PIANC Report N 121-2014, Maritime Navigation Commission.

Barker, C. H., (2015), New Developments in the General NOAA Operational Modeling Environment (GNOME), Proc. Interspill, Amsterdam, Netherlands, March 25, availabel at: http://interspill.org/previous-events/2015/WhitePapers/ Interspill2015ConferenceProceedings/25\%20MARCH\%202015/Developments\%20 in\%20Modelling/New-Developments-General-NOAA\%200perational-ModelingEnvironment-(GNOME).pdf

Belamarić G., (2015), Model za tite broda od piratskih napada, PhD thesis, Rijeka:
University of Rijeka, Faculty of Maritime Studies in Rijeka.

BERR - 2008 Information Security Breaches Survey: technical report, (2008), Technical report, London: Department for Business Enterprise \& Regulatory Reform Information Security Breaches.

Bleakley C., Kelleher G. and Wells, S., (1995), A global representative system of marine protected areas, Washington: Environment Department-The World Bank.

Buk a, J. and Zec, D., (2005), Model procjene pomorskih rizika u ograničenom plovnom području, Pomorstvo, Scientific Journal of Maritime Research, 19(1), pp. 173193.

Department for Business Innovation \& Skills, available at: http://www.bis.gov.uk/ files/file45714.pdf, [accessed 3 May 2015.].

Đurđević-Toma , I., Brajović, M. and Kurtela., (2010), Analiza rizika pomorskoga prometa u dubrovačkom akvatoriju, Na e more 57 (5-6), pp. 215225.

Fate of Spilled Oil in Marine Waters, (1999), API, publication 4691, available at: http:// www.api.org/oilspills/, [accessed 1 October 2015.].

Gibbs, M. T. and Browman, H. I., (2014), Risk Assessment and Risk Management: a Primer for Marine Scientists, ICES Journal of Marine Science, 72(3), pp. 992 996., http://dx.doi.org/10.1093/icesjms/fsu232

GNOME, available at: http://gcmd.nasa.gov/records/GNOME-NOAA.html, [accessed 2 October 2015.]

Guide to British Standards BS 7799 Risk Assessment; ISO Standard ISO/IEC TR 133353 , Information technology Guidelines for the management of IT security, 1st edition, 1998

Guttman, B. and Bagwill, R., (2010), A Technical Guide, NIST International Standard ISO/IEC 17799, available at: http://www.rxn.com/services/faq/internet/ISPTG.html, [accessed 2 October 2015.]

Hutinski, T. and Krakar Z., (2002), Procjena rizika kao dio sustava upravljanja sigurno ću informacija, Proc. CASE14., Opatija, June 3 - 7 .

Kontovas, C.A. and Psaraftis, H. N., (2010), Marine environment risk assessment: A survey on the disutility cost of oil spills, Proc. 2nd International Symposium on Ship Operations, Management \& Economics, Athens, Greece, September 17 18, pp. 275287

Kurtela, ., (2009), Upravljanje rizikom u pomorstvu, radni materijali s predavanja, Dubrovnik, University of Dubrovnik.

Response Tools for Oil Spills, available at: http://response.restoration.noaa.gov/ software/software.html, [accessed 10 May 2016.].

RIAM, availabe at: http://www.riam.kyushu-u.ac.jp/ vsm/, [accessed 2 October 2015.].

Risk Assesment Template, (2015), available at: http://www.ucalgary.ca/pmoancillary/ Templates/risk_assessment\%2008feb12.xls, [accessed 4 May 2015.].

Rutz, L. K. and Vines, R. D., (2001), The CISSP Prep Guide - Mastering the Ten Domains of Computer Security, Toronto: John Wiley \& Sons, Inc.

Statistički meteorolo ki podatci za područje akvatorija luke Šibenik, Dr avni zavod za statistiku: Priopćenja o kru nim putovanjima stranih brodova u Republici Hrvatskoj, available at: http://www.dzs.hr, [accessed 2 October 2015.].

The International Tanker Owners Pollution Federation Limited (ITOPF), http://www. itopf.com/knowledge-resources/data-statistics/statistics/, [accessed 12 June 2016.].

TRANSAS SIMULATION Software Program for Oil Spill Control/Manual; The PISCES2 - Potential Incident Simulation, Control and Evaluation System, (2015), Sankt Peterburg: TRANSAS LTD.tv vv 
Transport of Pollutants in the Air and the Sea of East Asia, (2000), Research Institute for Applied Mechanics, Kyushu University, Fukuoka, Japan, October 16-26.

Varlamov, S. M. and Abe, K., (2000), Oil Spill Initial Stage Spreading and Physical Properties Model, Reports of Research Institute for Applied Mechanics, Kyushu University, 119, pp. 89101.

Varlamov, S. M., Yoon, J. H., Nagaishi, H. and Abe, K., (2000), Japan Sea Oil Spill Analysis and Quick Response System with Adaptation of Shallow Water Ocean
Circulation Model, Reports of Research Institute for Applied Mechanics, Kyushu University, 118, pp. 922.

Varlamov, S., Yoon, J., Hirose, N., Kawamura, H. and Shiohara, K., (1999), Journal of Marine Science and Technology, 4(3), pp. 94-107.,

http://dx.doi.org/10.1007/s007730050012

Vidas, D., (2007), O za titi osobito osjetljivih europskih mora i potrebi regionalne suradnje u Jadranskome moru. Zagreb: kolska knjiga. 